\title{
Socio-Humanitarian Training Arrangement Technology Implementation for the Future Masters of Natural Specialties under the Distance Learning Conditions
}

\author{
Popenko N.* \\ V.N. Karazin Kharkiv National University, Kharkiv, Ukraine
}

Received: 12.03 .2020

Accepted: 27.03 .2020

\begin{abstract}
The article is concerned with the coverage of the stages content of the experiment on the practical implementation of the socio-humanitarian training arrangement technology for the future Masters of Natural Sciences under the distance learning conditions and the analysis of the results obtained. The tasks of research and experimental work are defined, namely: approbation of the socio-humanitarian training arrangement technology for the future Masters of Natural Sciences under the distance learning conditions; diagnostics of socio-humanitarian competence levels of the future Masters of Natural Sciences before and after the experiment; processing of experimental data by methods of mathematical statistics in order to increase the conclusionsvalidity. The essence of the ascertaining the stage of the experiment which defined the level of awareness of teachers working with the Masters of Natural Sciences, the possibilities of distance learning technologies and readiness to use them in the educational process; the level of attitude of the future Masters of Natural Sciences to study socio-humanitarian sciences and the use of distance technologies in the educational process; the levels of socio-humanitarian competence formation according to cognitive, motivational, value and communicative criteria are determined. At the formative stage of the experiment, methodological seminars on the general topic "Distance Learning Technologies a Requirement of the Present" were held for the teachers. The content of socio-humanitarian disciplines "Factors of Successful Employment in the Specialty" and "Higher Education Pedagogy" has been updated, the distance training courses of these disciplines in the Moodle distance learning system have been developed and introduced into the educational process. The complex of active teaching methods such as: problem-based learning method, brainstorming, case-method, project method, business games, practical exercises, analysis of specific pedagogical situationis applied. The effectiveness of implementation of the socio-humanitarian training arrangement technology for the future Masters of Natural Sciences under the distance learning conditionsis reflected in dynamics of levels of socio-humanitarian competence formation in future Masters of control and experimental groups. The validity of the results recorded during the pedagogical experiment was confirmed by the Pearson test.
\end{abstract}

Key words: experiment, technology, Masters of Natural Sciences, socio-humanitarian competence, distance learning.

\section{Реалізація технології організації соціально-гуманітарної підготовки майбутніх магістрів природничих спеціальностей в умовах дистанційного навчання}

\author{
Попенко Н. В. \\ Харківський національний університет імені В.Н. Каразіна, Харків, Україна
}

\begin{abstract}
Анотація. Статтю присвячено висвітленню змісту етапів експерименту щодо практичної реалізації технології організації соціально-гуманітарної підготовки майбутніх магістрів природничих спеціальностей в умовах дистанційного навчання та здійсненню аналізу отриманих результатів. Визначено завдання дослідноекспериментальної роботи, а саме: апробацію технології організації соціально-гуманітарної підготовки майбутніх магістрів природничих спеціальностей в умовах дистанційного навчання; діагностику рівнів сфрормованості соціально-гуманітарної компетентності майбутніх магістрів природничих спеціальностей до та після експерименту; опрацювання експериментальних даних методами математичної статистики з метою підвищення обгрунтованості висновків. Розкрито сутність констатувального етапу експерименту, на якому
\end{abstract}

Corresponding Author: Popenko Nataliia Volodymyrivna, Tel. +38 (063) 4000613 .E-mail: popenko_nata@ukr.net V.N.Karazin Kharkiv National University, 4 Svobody Sq., Kharkiv, Ukraine, 61022.

Відповідальний автор: Попенко Наталія Володимирівна, Тел. (063) 4000613 . E-mail: popenko_nata@ukr.net Харківський національний університет імені В.Н. Каразіна, Майдан Свободи, 4, м. Харків, Україна, 61022. 
було визначено рівень обізнаності викладачів, що працюють з магістрами природничих спеціальностей, про можливості дистанційних технологій навчання та готовності до використання їх в освітньому процесі; визначено рівень ставлення майбутніх магістрів природничої галузі до вивчення соціально-гуманітарних дисциплін та використання дистанційних технологій в освітньому процесі; визначено рівні сформованості соціально-гуманітарної компетентності за когнітивним, мотиваційно-ціннісним та комунікативним критеріями. На формувальному етапі експерименту було проведено методичні семінари для викладачів на загальну тему «Дистанційні технології навчання - вимога сьогодення». Проведено оновлення змісту соціально-гуманітарних дисциплін «Чинники успішного працевлаштування за фахом» та «Педагогіка вищої школи», розроблено дистанційні навчальні курси цих дисциплін в системі дистанційного навчання Moodle та впроваджено їх у в освітній процес. Застосовано комплекс активних методів навчання таких як: метод проблемного навчання, мозковий штурм, кейс-метод, метод проектів, ділові ігри, практичні вправи, аналіз конкретних педагогічних ситуацій Ефективність реалізації технології організації соціально-гуманітарної підготовки майбутніх магістрів природничих спеціальностей в умовах дистанційного навчання відображено у динаміці рівнів сформованості соціально-гуманітарної компетентності у майбутніх магістрів контрольної та експериментальної груп. Достовірність результатів зафріксованих під час проведення педагогічного експерименту підтверджена за допомогою критерію Пірсона.

Ключові слова: експеримент, технологія, магістри природничих спеціальностей, соціально-гуманітарна компетентність, дистанційне навчання.

\title{
Реализация технологии организации социально-гуманитарной подготовки будущих магистров естественных специальностей в условиях дистанционного обучения
}

Попенко Н. В.

\author{
Харьковский национальный университет имени В.Н. Каразина, Харьков, Украина
}

\begin{abstract}
Аннотация. Статья посвящена освещению содержания этапов эксперимента по практической реализации технологии организации социально-гуманитарной подготовки будущих магистров естественных специальностей в условиях дистанционного обучения и осуществлению анализа полученных результатов. Определены задачи опытно-экспериментальной работы, а именно: апробацию технологии организации социально-гуманитарной подготовки будущих магистров естественных специальностей в условиях дистанционного обучения; диагностику уровней сформированности социально-гуманитарной компетентности будущих магистров естественных специальностей до и после эксперимента; обработки экспериментальных данных методами математической статистики с целью повышения обоснованности выводов. Раскрыта сущность констатирующего этапа эксперимента. Определен уровень осведомленности преподавателей, работающих с магистрами естественных специальностей, о возможности дистанционных технологий обучения и готовности к использованию их в образовательном процессе; определен уровень отношения будущих магистров естественной области к изучению социально-гуманитарных дисциплин и использования дистанционных технологий в образовательном процессе; определены уровни сформированности социальногуманитарной компетентности по когнитивному, мотивационно-ценностному и коммуникативному критериям. На формирующем этапе эксперимента были проведены методические семинары для преподавателей на общую тему «Дистанционные технологии обучения - требование современности». Проведено обновление содержания социально-гуманитарных дисциплин «Факторы успешного трудоустройства по специальности» и «Педагогика высшей школы», разработан дистанционные учебные курсы этих дисциплин в системе дистанционного обучения Moodle и внедрение их в в образовательный процесс. Применен комплекс активных методов обучения. Таких как: метод проблемного обучения, мозговой штурм, кейс-метод, метод проектов, деловые игры, практические упражнения, анализ конкретных педагогических ситуаций Эффективность реализации технологии организации социально-гуманитарной подготовки будущих магистров естественных специальностей в условиях дистанционного обучения отражено в динамике уровней сформированности социально-гуманитарной компетентности у будущих магистров контрольной и экспериментальной групп. Достоверность результатов зафиксированных во время проведения педагогического эксперимента подтверждена с помощью критерия Пирсона..
\end{abstract}

Ключевые слова: эксперимент, технология, магистры естественных специальностей, социальногуманитарная компетентность, дистанционное обучение.

\section{Bcmyn}

Стан розвитку людської цивілізації на початку третього тисячоліття характеризується цілою низкою соціальних трансформацій у напрямку глобалізації та інформатизації. Сучасна Україна перебуває у стані пошуку свого європейського шляху розвитку, налагоджує культурні, економічні, 
політичні, суспільні та інші зв'язки. Для успішного подолання означених процесів нам необхідно чітко визначитися яких професіоналів і для якого суспільства ми повинні готувати. Стрімкі інформаційнотехнологічні революції та динамічність соціальних процесів, усвідомлення того фракту, що освіта є основою економічної та суспільної заможності держави, змінюють вимоги до майбутніх фахівців природничої галузі. Адже, саме вони формують науково-дослідницький корпус країни, який забезпечує її матеріально-технічний розвиток.

Жорстка конкуренція на ринку праці, що постійно змінюється, висуває нові вимоги до змісту підготовки майбутніх магістрів природничих спеціальностей. Сьогодення зумовлює появу фахівця нової генерації: професійно і соціально мобільного; відповідального за наслідки своєї діяльності; такого, який має глибокі фундаментальні, професійні та соціально-гуманітарні знання; здатний до технічної та соціальної творчості, постійного самовдосконалення та самоосвіти; готовий працювати у конкурентних умовах. Отже, зміст освіти мусить стати важливим засобом духовного, соціального і політичного розвитку суб'єкта, мати гуманістичну спрямованість [1]. Тому, важливим напрямом процесу професійного становлення майбутнього магістра природничого спрямування у закладі вищої освіти (3ВО) $€$ соціально-гуманітарна підготовка, під час якої здобувачі освіти засвоюють гуманістичні цінності, загальнолюдську культуру та важливі світоглядні принципи. За визначенням Г. Лесик [2] соціально-гуманітарна підготовка у 3ВО є стратегічним напрямом освіти, що уможливлює формування фрахівця як творчої особистості, який визначається професійністю і стійкими соціально-психологічними якостями. Результатом соціально-гуманітарної підготовки майбутніх магістрів природничих спеціальностей є сформованість соціально-гуманітарної компетентності. Високий рівень сформованості соціально-гуманітарної компетентності майбутнього магістра природничого спрямування дозволить йому перебувати на високому професійному рівні та розвивати культуру своєї діяльності.

Однак, аналіз освітніх програм провідних 3ВО України у контексті соціально-гуманітарної підготовки як однієї із складових професійної підготовки майбутніх магістрів природничого спрямування свідчить про те, що дана складова репрезентована у програмах недостатньо і не повною мірою відповідає очікуваним результатам навчання. Також спостерігається обмеження часу на засвоєння соціально-гуманітарних дисциплін. Даний фракт привернув увагу і Національного агентства із забезпечення якості вищої освіти, голова агентства С. Квіт [3] зазначає, що останнім часом у ЗВО спостерігається тенденція до неправомірного звуження освітніх компонентів лише до фахових, що в українських реаліях призводить до втрати універсальності й комплексності вищої освіти. Посилання на університетську автономію або формальна наявність окремих вибіркових гуманітарних дисциплін в сучасних умовах позбавлені сенсу. Автономія університетів має спиратися на відповідальність ЗВО за якість власних освітніх програм, які мають забезпечувати не лише фрахову підготовку, а й всебічний гармонійний розвиток особистості здобувача освіти.

У якості одного із шляхів подолання вищеназваної проблеми, ми вбачаємо зміну підходів до викладання соціально-гуманітарних дисциплін, а саме використання дистанційних технологій в освітньому процесі. Це сприятиме індивідуалізації процесу професійного становлення майбутніх магістрів природничої галузі, буде спонукати їх до самостійної роботи, формуватиме інформаційну культуру, налаштовуватиме на оволодіння новими способами здобуття та застосування знань.

Не зважаючи на досить широкий обсяг публікацій присвячених проблемам соціально-гуманітарної підготовки фрахівців негуманітарного профрілю, які знайшли своє відображення у дослідженнях О. Квасник, Н. Мачинської, Н. Микитенко, Л. Перевалової, Т. Поясок, О. Романовського, О. Федорцової, О. Шевченко; сучасним аспектам теорії і практики дистанційного навчання (ДН), проблемам впровадження дистанційних технологій у освітній процес ЗВО присвячено роботи В.Бикова, Н. Жевакіної, В. Кухаренка, В. Олійника, В. Осадчего, К. Осадчої, П. Стефаненка, О. Хмель; проблема організації соціально-гуманітарної підготовки майбутніх магістрів природничих спеціальностей в умовах дистанційного навчання ще не була предметом окремого наукового дослідження.

Розробка, проєктування та обгрунтування технології організації соціально-гуманітарної підготовки майбутніх магістрів природничих спеціальностей в умовах дистанційного навчання стала спробою вирішення означеної проблеми. Ефективність розробленої технології було перевірено під час педагогічного експерименту. 
Mema cmammi полягає у висвітленні змісту етапів експериментальної роботи щодо практичної реалізації технології організації соціально-гуманітарної підготовки майбутніх магістрів природничих спеціальностей в умовах дистанційного навчання та проведенні аналізу отриманих результатів.

\section{II Матеріал і методи дослідження}

Теоретичний аналіз сучасного стану соціально-гуманітарної підготовки магістрів природничого спрямування у 3ВО, вивчення можливостей впровадження елементів ДН у процес організації соціальногуманітарної підготовки магістрів природничої галузі стали підґрунтям для розробки технології організації соціально-гуманітарної підготовки майбутніх магістрів природничих спеціальностей в умовах дистанційного навчання: визначити мету, наукові підходи, упорядкувати принципи, виділити організаційно-педагогічні умови, обрати оптимальний інструментарій для реалізації дистанційного освітнього процесу, визначити критерії, за допомогою яких можна оцінити рівень сформованості соціально-гуманітарної компетентності майбутніх магістрів природничих спеціальностей. Тому логічним підсумком даного дослідження стала експериментальна перевірка ефективності розробленої технології.

Експеримент (від лат. experimentum - проба, досвід) визначається як планомірно проведене спостереження; планомірна ізоляція, комбінація і варіювання умов з метою вивчення залежних від них явищ [4]. Науковці визначають експеримент у педагогічній діяльності як метод педагогічних досліджень, під час якого відбувається активний вплив на педагогічні явища шляхом створення нових умов, що відповідають меті дослідження (С. Сисоєва [5]); як строго спрямовану і контрольовану педагогічну діяльність зі створення та апробації нових технологій навчання, виховання, розвитку особистості; як спеціально організовану перевірку того чи іншого методу., прийому роботи для виявлення його педагогічної ефективності (3. Курлянд [6]).

Ми будемо послуговуватися визначенням наведеним у словнику термінів з педагогіки вищої школи [7], педагогічний експеримент - це науково організований дослід у галузі навчання чи виховання для пошуку нових, більш ефективних способів розв'язання педагогічної проблеми, дослідницька діяльність з вивчення причинно-наслідкових зв'язків у педагогічних явищах, яка передбачає їх моделювання й умови перебігу; активний вплив дослідника на педагогічне явище, вимірювання змін, викликаних упровадженням нової моделі, неодноразова відтворюваність педагогічних явищ і процесів.

При підготовці та проведенні педагогічного експерименту ми спиралися на теоретичні знання, рекомендації щодо методики проведення педагогічних досліджень та досвід організації експериментальних досліджень та обробки їх результатів таких вчених як Ю. Бабанський, П. Воловик, Б. Гершунський, С. Гончаренко, Н. Кузьміна та ін.

Зважаючи на основні вимоги, що висуваються до організації педагогічного експерименту, мета проведеного нами експериментального дослідження полягала у перевірці ефективності розробленої технології організації соціально-гуманітарної підготовки майбутніх магістрів природничих спеціальностей в умовах дистанційного навчання, що складається із сукупності таких етапів реалізації: методологічно-цільового, змістово-організаційного, контрольно-результативного.

Завдання дослідно-експериментальної роботи передбачали:

- апробацію авторської технології організації соціально-гуманітарної підготовки майбутніх магістрів природничих спеціальностей в умовах дистанційного навчання;

- діагностику рівнів сфрормованості соціально-гуманітарної компетентності майбутніх магістрів природничих спеціальностей до та після експерименту;

- опрацювання отриманих експериментальних даних методами математичної статистики з метою підвищення обґрунтованості висновків.

Дослідно-експериментальна робота тривала протягом 2014-2019 років та охоплювала такі етапи науково-педагогічного пошуку: аналітично-пошуковий, експериментальний та узагальнюючий.

На першому аналітично-пошуковому етапі, який тривав протягом 2014-2016 рр. було проведено вивчено та проаналізовано стан розробленості проблеми педагогічного дослідження у сучасній науковій психолого-педагогічній та методичній літературі; визначено загальні теоретичні та методологічні основи дослідження; обґрунтовано актуальність теми дослідження, конкретизовано об'єкт, предмет, мету та завдання дослідження; науково обґрунтовано понятійно-категоріальний апарат дослідження; розроблено технологію організації соціально-гуманітарної підготовки майбутніх магістрів природничих 
спеціальностей в умовах дистанційного навчання; визначено кількісний та якісний склад учасників експерименту.

На другому експериментальному етапі (2016-2019рр.) дослідно-експериментальним шляхом було перевірено гіпотезу, апробовано авторську технологію організації соціально-гуманітарної підготовки майбутніх магістрів природничих спеціальностей в умовах дистанційного навчання, здійснено аналіз результатів контрольних зрізів та здійснено корекцію методів і форм експериментальної роботи.

На третьому узагальнюючому етапі дослідження (2019р.) було здійснено систематизацію, узагальнення, обробку емпіричних даних та зіставлення одержаних експериментальних результатів 3 прогнозованими; сформульовано загальні висновки дослідження та визначено подальші напрями наукових розвідок означеної проблеми.

У нашому дослідженні було передбачене використання методів наукового дослідження, зокрема: емпіричні (педагогічне спостереження, опитування, бесіда, анкетування, тестування, педагогічний експеримент), теоретичні (метод вивчення наукової літератури, сходження від абстрактного до конкретного, аналіз і синтез, порівняння), математичної статистики.

Експериментальною базою дослідження став Харківський національний університет імені В.Н.Каразіна, педагогічним експериментом було охоплено 248 студентів та 27 викладачів (10 викладачів соціально-гуманітарних дисциплін та 18 викладачів спеціальних дисциплін).

Констатувальний етап експерименту, який було проведено у природних умовах освітнього процесу ЗВО передбачав вирішення наступних завдань:

- визначити рівень обізнаності викладачів, що працюють 3 магістрами природничих спеціальностей, про можливості дистанційних технологій навчання та готовності до використання їх в освітньому процесі;

- визначити рівень ставлення майбутніх магістрів природничої галузі до вивчення соціальногуманітарних дисциплін та використання дистанційних технологій в освітньому процесі;

- визначення рівня сфрормованості соціально-гуманітарної компетентності за когнітивним, мотиваційно-ціннісним та комунікативним критеріями.

Для забезпечення репрезентативності контрольних (далі КГ) та експериментальних (далі ЕГ) груп нами було застосовано спосіб випадкового відбору груп - механічний відбір. Під час механічного відбору ми виписали послідовний ряд номерів груп, а над ними виписали випадкові числа. Потім обирали по порядку дев'ять найменших цифр та відповідні їм групи; чотири групи, що відповідали меншим цифрам стали експериментальними, а чотири групи, що відповідали більшим цифрам контрольними. Таким чином, до ЕГ увійшло 117 студентів, до КГ - 131 студент.

3 метою визначення стану початкової обізнаності та готовності до використання елементів ДН під час соціально-гуманітарної підготовки на констатувальному етапі експерименту були проведені спостереження, бесіди та анкетування серед викладачів, що працюють з магістрами природничого спрямування. Для цього були розроблені авторські анкету для викладачів з питаннями про їх готовність до використання дистанційного навчання. Результати анкетування продемонстрували, що більшість викладачів (85,7\%), які брали участь в анкетуванні, одностайні в одному: необхідно вивчати досвід використання ДН та брати активну участь у розробці дистанційних курсів з метою підвищення рівня самоосвіти та опанування інформаційних технологій у навчанні.

На констатувальному етапі експерименту було проведення також анкетування щодо визначення ставлення до дистанційних технологій в освітньому процесі та взагалы до вивчення соціальногуманітарних дисциплін і серед майбутніх магістрів. Для вирішення цього завдання було розроблено анкету для студентів.

Аналіз проведеного анкетування серед майбутніх магістрів природничого спрямування щодо їх ставлення до використання дистанційних технологій в освітньому процесі та вивчення соціальногуманітарних дисциплін продемонстрував наступне:

- в цілому студенти мають позитивне ставлення до ДН у якості додаткової форми навчання;

- студенти на достатньому рівні володіють інформаційними технологіями та впевнено використовують мережу Інтернет при опанування освітніх програм на яких навчаються;

- студенти в цілому мають уявлення про системами ДН, оскільки під час навчання викладачі використовують окремі їх елементи; 
- більше половини опитаних студентів вважають, що отримують достатню соціально-гуманітарну освіту у своєму ЗВО та впевнені у тому, що у побудові майбутньої кар'єри соціально-гуманітарні знання гратимуть вагому роль;

- значна частина респондентів не задоволена вибором та якістю викладання соціальногуманітарних дисциплін через те, що більшість викладачів або не враховує, або враховує лише частково профріль професійної підготовки майбутніх магістрів під час викладання соціальногуманітарних дисциплін;

- майбутні магістри мають високий ступінь зацікавленості використанні елементів ДН при вивченні соціально-гуманітарних дисциплін.

\section{III Результати}

3 метою отримання первинних даних про початковий стан сформованості соціально-гуманітарної компетентності за когнітивним критерієм нами було проведено вхідний тестовий контроль 3 дисциплін «Чинники успішного працевлаштування за фахом» та «Педагогіка вищої школи». При розробці тестових завдання для вхідного контролю знань ми спиралися на те, що майбутні магістри вже мають базові знання з визначених дисциплін завдяки соціально-гуманітарним дисциплінам, що вивчалися ними під час опанування освітньої програми бакалавра. Тестування було проведено з дотриманням вимог об'єктивності, надійності та раціональної організації. Оцінювання тестового вхідного контролю здійснювалося за 100-бальною шкалою з подальшим переведенням у визначені нами рівні: 100-85 балів - високий рівень, 84-65 балів - достатній рівень, 64-0 балів - низький рівень. Для більш високої об'єктивності констатувального експерименту ми також врахували попередні навчальні досягнення студентів КГ та ЕГ, а саме загальний середній бал успішності груп та середній бал успішності із соціально-гуманітарних дисциплін згідно додатків до дипломів бакалавра. Для проведення розрахунків ми використовували програму Microsoft Excell, що входить до пакету програм Microsoft Office.

Для визначення рівня сфрормованості соціально-гуманітарної компетентності майбутніх магістрів природничих спеціальностей за мотиваційно-ціннісним критерієм у дослідженні використано методику для діагностики навчальної мотивації студентів (А. Реан, В. Якунін у модифікації Н. Бадмаєвої) [8], методику діагностики реальної структури ціннісних орієнтацій особистості (С. Бубнова) [9], методику визначення спрямованості особистості (Б. Басс) [10].

Для визначення рівня сформованості соціально-гуманітарної компетентності майбутніх магістрів природничих спеціальностей за комунікативним критерієм під час експериментального дослідження нами були використані методика оцінки комунікабельності (В. Ряховський) [11] та оцінювання рівня розвитку комунікативних та організаторських здібностей «КОЗ-2» (Б. Федоришин) [12].

Отримана під час констатувального етапу експерименту інформація уможливила визначити узагальнені дані про рівень сформованості соціально-гуманітарної компетентності компетентності майбутніх магістрів природничих спеціальностей (табл. 1).

Узагальнення результатів дослідження констатувального етапу експерименту продемонструвало: високий рівень соціально-гуманітарної компетентності майбутніх магістрів природничих спеціальностей виявлено у $30,77 \%$ магістрів ЕГ та у $30,53 \%$ магістрів КГ, середній рівень - у 38,46\% здобувачів освіти ЕГ та у $37,40 \%$ здобувачів освіти КГ, низький рівень зафріксовано у $30,77 \%$ учасників експерименту ЕГ та у 32,06\% учасників експерименту КГ відповідно. Відображені результати у таблиці 1 наочно представимо у вигляді діаграм (рис. 1).

Таким чином, результат констатувального етапу педагогічного експерименту продемонстрував низький рівень сфрормованості соціально-гуманітарної компетентності майбутніх магістрів природничих спеціальностей як у експериментальній так і у контрольній групах, що потребувало впровадження системи педагогічних заходів для покращення досліджуваного показника.

Сутність формувального етапу педагогічного експерименту (2016-2019рр.) полягала у впровадженні технології організації соціально-гуманітарної підготовки майбутніх магістрів природничих спеціальностей в умовах дистанційного навчання в освітній процес $3 \mathrm{BO}$, а саме реалізацію їі методологічно-цільового, змістово-організаційного та контрольно-результативного етапів. Мета означеної технології полягала у підвищенні ефективності соціально-гуманітарної підготовки майбутніх магістрів природничих спеціальностей в умовах дистанційного навчання, а результат передбачав 
сформованість соціально-гуманітарної компетентності майбутніх магістрів природничих спеціальностей. Для кожного з етапів технології визначалася мета, завдання та навчально-методичний механізм реалізації.

Табл. 1. Рівні сформованості соціально-гуманітарної компетентності майбутніх магістрів природничих спеціальностей (констатувальний етап)

\begin{tabular}{|c|c|c|c|c|}
\hline \multirow{2}{*}{$\begin{array}{l}\text { Групи } \\
\text { Рівень }\end{array}$} & \multicolumn{2}{|c|}{ ЕГ (117 осіб) } & \multicolumn{2}{|c|}{ КГ (131 особа) } \\
\hline & K-Tb & $\%$ & K-Tb & $\%$ \\
\hline \multicolumn{5}{|c|}{ Когнітивний критерій } \\
\hline Високий & 33 & 28,20 & 35 & 26,71 \\
\hline Середній & 46 & 39,31 & 50 & 38,18 \\
\hline Низький & 38 & 32,49 & 46 & 35,11 \\
\hline \multicolumn{5}{|c|}{ Мотиваційно-ціннісний критерій } \\
\hline Високий & 50 & 42,73 & 55 & 41,98 \\
\hline Середній & 40 & 34,18 & 44 & 33,59 \\
\hline Низький & 27 & 23,07 & 32 & 24,43 \\
\hline \multicolumn{5}{|c|}{ Комунікативний критерій } \\
\hline Високий & 24 & 20,51 & 30 & 22,90 \\
\hline Середній & 49 & 41,88 & 54 & 41,22 \\
\hline Низький & 44 & 37,61 & 47 & 35,88 \\
\hline \multicolumn{5}{|c|}{ Загальний результат } \\
\hline Високий & 36 & 30,77 & 40 & 30,53 \\
\hline Середній & 45 & 38,46 & 49 & 37,40 \\
\hline Низький & 36 & 30,77 & 42 & 32,06 \\
\hline
\end{tabular}

Експериментальна група (117 осіб)

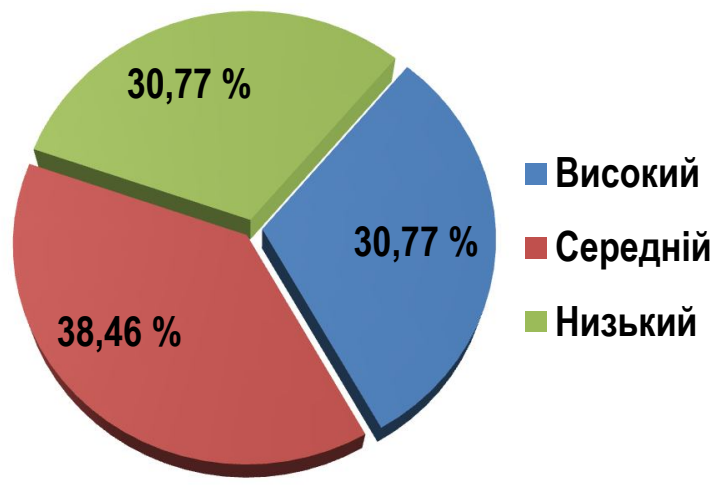

Контрольна група

(131 особа)

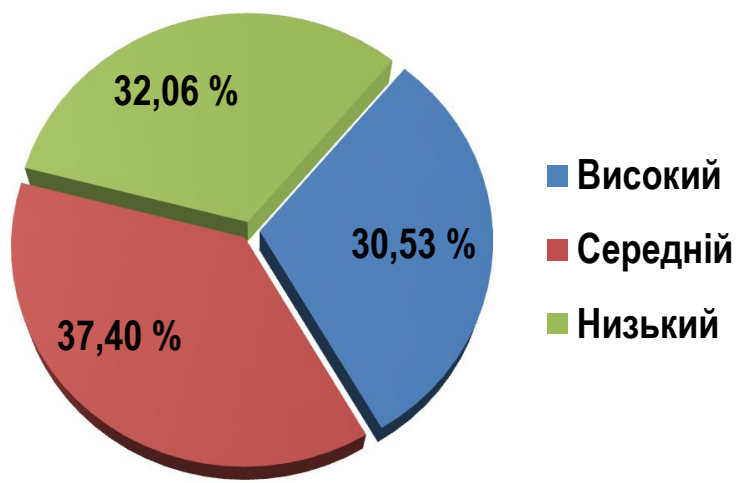

Рис. 1. Вихідні результати соціально-гуманітарної компетентності майбутніх магістрів природничих спеціальностей (констатувальний етап)

Зауважимо, що для майбутніх магістрів експериментальної групи процес соціально-гуманітарної підготовки здійснювався дистанційно шляхом запровадження розробленої технології, а для магістрів контрольної групи процес соціально-гуманітарної підготовки відбувався традиційним способом.

На методологічно-цільовому етапі реалізації технології нами було визначено загальну мету, наукові підходи: компетентнісний, системний, діяльнісний, особистісно-орієнтований та дидактичні принципи (системності, науковості, проблемності, особистісно-опосередкованої взаємодії, 
інтерактивності, стартового рівня знань, індивідуалізації, ідентифікації, педагогічної доцільності застосування нових інформаційних технологій, регламентування навчання, мобільності навчання).

На змістово-організаційному етапі були виокремлено організаційно-педагогічні умови підвищення ефективності соціально-гуманітарної підготовки магістрів природничих спеціальностей в умовах дистанційного навчання, а саме: готовність науково-педагогічних працівників (НПП) до використання елементів дистанційного навчання в освітньому процесі; забезпечення мотивації майбутніх магістрів природничої галузі до навчання у дистанційному середовищі; наявність якісного навчальнометодичного, матеріально-технічного та програмного забезпечення дистанційного навчання; також нами було проаналізовано та досліджено можливості платформи дистанційного навчання MOODLE, як засобу підвищення ефективності соціально-гуманітарної підготовки майбутніх магістрів природничих спеціальностей; визначено структуру та особливості побудови дистанційних навчальних курсів «Чинники успішного працевлаштування за фрахом» та «Педагогіка вищої школи»; здійснено комплексний аналіз, відбір та висвітлення змісту, форм, методів, засобів педагогічної діяльності у дистанційному освітньому середовищі задля досягнення кінцевого результату, а саме: сфрормованості соціальногуманітарної компетентності майбутніх магістрів природничих спеціальностей.

Під час формувального етапу експерименту нами було враховано результати анкетування викладачів і у якості допомоги для них було організовано та проведено методичні семінари на загальну тему «Дистанційні технології навчання - вимога сьогодення». Значну увагу під час проведення семінарів було присвячено таким питанням як: «Стан та перспективи дистанційного навчання у закладах вищої освіти країни», «Переваги та недоліки дистанційного навчання», «Зміна ролі викладача при організації дистанційного навчання» «Використання сучасної платформи Moodle для створення навчальних курсів», «Інструментарій платформи Moodle для проектування дистанційних навчальних курсів», «Презентація курсів, створених у Moodle». В результаті проведених семінарів, було актуалізовано у викладачів стійкий інтерес до колосальних можливостей для реалізації освітнього процесу підготовки магістрів, які надають дистанційні технології навчання та готовність створювати дистанційні освітні продукти. Було здійснено презентацію системи дистанційного навчання Moodle, яка надає викладачу широкий перелік можливостей для представлення навчально-методичних матеріалів курсу, проведення теоретичних та практичних занять та організації індивідуальної та групової навчальної діяльності. I хоча було зазначено, що не всі дисципліни доречно опановувати дистанційно, одностайної думки викладачі дійшли у тому, що використання окремих елементів дистанційного навчання може стати ефективним способом підвищення якості освіти під час не лише вивчення соціально-гуманітарних дисциплін, а й фахових.

Основним завданням формувального етапу експерименту стала практична апробація спроєктованої та науково обґрунтованої технології організації соціально-гуманітарної підготовки майбутніх магістрів природничих спеціальностей в умовах дистанційного навчання. Задля реалізації цього завдання нами було проведено оновлення, модифікація та корегування змісту соціальногуманітарних дисциплін «Чинники успішного працевлаштування за фрахом» та «Педагогіка вищої школи», що входять до вибіркових дисциплін циклу загальної підготовки магістрів галузі знань 10 Природничі науки та спеціальності 105 «Прикладна фрізика та наноматеріали», розроблено дистанційні навчальні курси цих дисциплін в системі дистанційного навчання Moodle та впроваджено їх у в освітній процес.

Модель розроблених дистанційних навчальних курсів має інтегрований характер і структурно складається з чотирьох функціонально-узгоджених блоків: інструктивний, навчально-інформаційний, комунікативний та контрольний [13].

Інструктивний блок містить: загальну інформацію про курс (що вивчає дисципліна, мета та завдання курсу, актуальність та практична значущість, зв'язок з іншими дисциплінами); навчальну програму курсу; рекомендації щодо організації процесу навчання; навчальний план та графрік вивчення дисципліни: назви тем та рекомендована послідовність їх вивчення; орієнтовна кількість годин на вивчення кожної теми курсу; теми дискусій (з переліком основних питань) та час їх проведення. Інструктивний блок також забезпечує реєстрацію студентів та збереження вхідних даних про них.

Навчально-інформаційний блок містить системний курс лекцій, завдань, практичних робіт, аудіота відео файли, інформаційні посилання, додаткову літературу в електронному вигляді, блок також 
надає необхідну інфрормацію за відповідним запитом студента: пояснення, зразки виконання вправ чи завдань, вказівки, коментарі.

Комунікативний блок є системою інтерактивного спілкування між викладачем та студентами та студентами між собою. Комунікативна діяльність студентів під час дистанційного навчання триває постійно й здійснюється за допомогою телеконференцій, електронної пошти, дискусій, чатів, сучасних месенджерів Skype, Whatsapp, Viber, Telegram. Спілкування може відбуватись і в синхронному, і в асинхронному режимі.

Контрольний блок містить механізми тестування, перевірки та оцінювання знань студентів, які мають і проміжний, і підсумковий характер [13].

У розроблених нами дистанційних курсах ми використовували цілу низку активних методів навчання для організації практичних занять, які сприяли формуванню соціально-гуманітарної компетентності майбутніх магістрів природничої галузі за усіма критеріями (табл. 2).

Табл. 2. Перелік активних методів навчання, використаних у дистанційних курсах на формувальному етапі експерименту

\begin{tabular}{|l|l|}
\hline \multicolumn{1}{|c|}{$\begin{array}{c}\text { Використання активних методів у курсі } \\
\text { «Чннники у спішного працевлаштування за } \\
\text { фахом» }\end{array}$} & \multicolumn{1}{|c|}{$\begin{array}{c}\text { Використання активних методів у курсі } \\
\text { «Педагогіка вищої школи» }\end{array}$} \\
\hline $\begin{array}{l}\text { Діалоги зі студентами під час занять протягом } \\
\text { усього періоду опанування курсу }\end{array}$ & $\begin{array}{l}\text { Діалоги зі студентами під час занять протягом } \\
\text { усього періоду опанування курсу. }\end{array}$ \\
\hline Метод проблемного навчання & Метод проектів \\
\hline Мозковий штурм & Кейс-метод \\
\hline Ділова гра & Аналіз конкретних педагогічних ситуацій \\
\hline $\begin{array}{l}\text { Проведено практичні вправи «Обери головне», } \\
\text { «Запитання-відповідь», «Казкове королівство», «Я } \\
\text {-найкращий» }\end{array}$ & $\begin{array}{l}\text { Проведено практичні вправи «Вікторина», } \\
\text { «Довідь», «Допитливий учень», «Конспект» }\end{array}$ \\
\hline
\end{tabular}

На узагальнюючому етапі експериментального дослідження (2019р.) було здійснено перевірку ефрективності впровадження технології організації соціально-гуманітарної підготовки майбутніх магістрів природничих спеціальностей в умовах дистанційного навчання в освітній процес 3ВО, яка проводилась на основі порівняльного методу наукового дослідження шляхом співставлення вихідних і кінцевих даних.

Задля систематизації експериментальних даних на контрольному етапі педагогічного експерименту нами було здійснено комплекс моніторингових дій щодо діагностики кінцевого рівня сформованості соціально-гуманітарної компетентності майбутніх магістрів природничих спеціальностей в умовах дистанційного навчання із застосуванням методів педагогічної діагностики обраних під час констатувального етапу експерименту.

Порівняльний аналіз результатів експериментального дослідження в ЕГ та КГ після проведення формувального етапу експерименту продемонструвало, що майбутні магістри природничого спрімування ЕГ істотно перевищили результати КГ за показниками усіх трьох критеріїв сформованості соціально-гуманітарної компетентності. Дані здійсненого аналізу дозволяють зробити висновок про ефективність впровадженої технології організації соціально-гуманітарної підготовки майбутніх магістрів в умовах дистанційного навчання у ЕГ.

Динаміку рівнів сформованості соціально-гуманітарної компетентності майбутніх магістрів природничих спеціальностей наведено в таблиці 3 та наочно продемонстровано на рисунку 2.

Узагальнені результати формувального етапу експериментального педагогічного дослідження щодо підвищення ефективності соціально-гуманітарної підготовки майбутніх магістрів природничих спеціальностей в умовах дистанційного навчання, результатом якої мала стати сформованість соціально-гуманітарної компетентності вищеназваних здобувачів освіти уможливили з'ясувати, що:

- 48,72\% майбутніх магістрів ЕГ володіють означеною компетентністю на високому рівні проти $35,88 \%$ майбутніх магістрів КГ; 
- 43,59\% майбутніх магістрів ЕГ володіють соціально-гуманітарною компетентністю на середньому рівні, тоді як у КГ таких здобувачів освіти 39,69\%;

- низький рівень сформованості вищеназваної компетентності більшою мірою притаманний майбутнім магістрам КГ 24,43\% у порівнянні із майбутніми магістрами ЕГ - 7,69\%.

Табл. 3. Динаміка рівнів сфрормованості соціально-гуманітарної компетентності майбутніх магістрів природничих спеціальностей до та після експерименту

\begin{tabular}{|c|c|c|c|c|c|c|c|c|}
\hline \multirow{2}{*}{ Етапи / Групи } & \multicolumn{4}{|c|}{ Констатувальний етап } & \multicolumn{4}{c|}{ Контрольний етап } \\
\hline \multirow{2}{*}{ Рівні } & ЕГ (117 осіб) & \multicolumn{2}{|c|}{ КГ (131 особа) } & \multicolumn{2}{|c|}{ ЕГ (117 осіб) } & \multicolumn{2}{|c|}{ КГ (131 особа) } \\
\cline { 2 - 9 } & К-ть & $\%$ & К-ть & $\%$ & К-ть & $\%$ & К-ть & $\%$ \\
\hline Високий & 36 & 30,77 & 40 & 30,53 & 57 & 48,72 & 47 & 35,88 \\
\hline Середній & 45 & 38,46 & 49 & 37,40 & 51 & 43,59 & 52 & 39,69 \\
\hline Низький & 36 & 30,77 & 42 & 32,06 & 9 & 7,69 & 32 & 24,43 \\
\hline
\end{tabular}

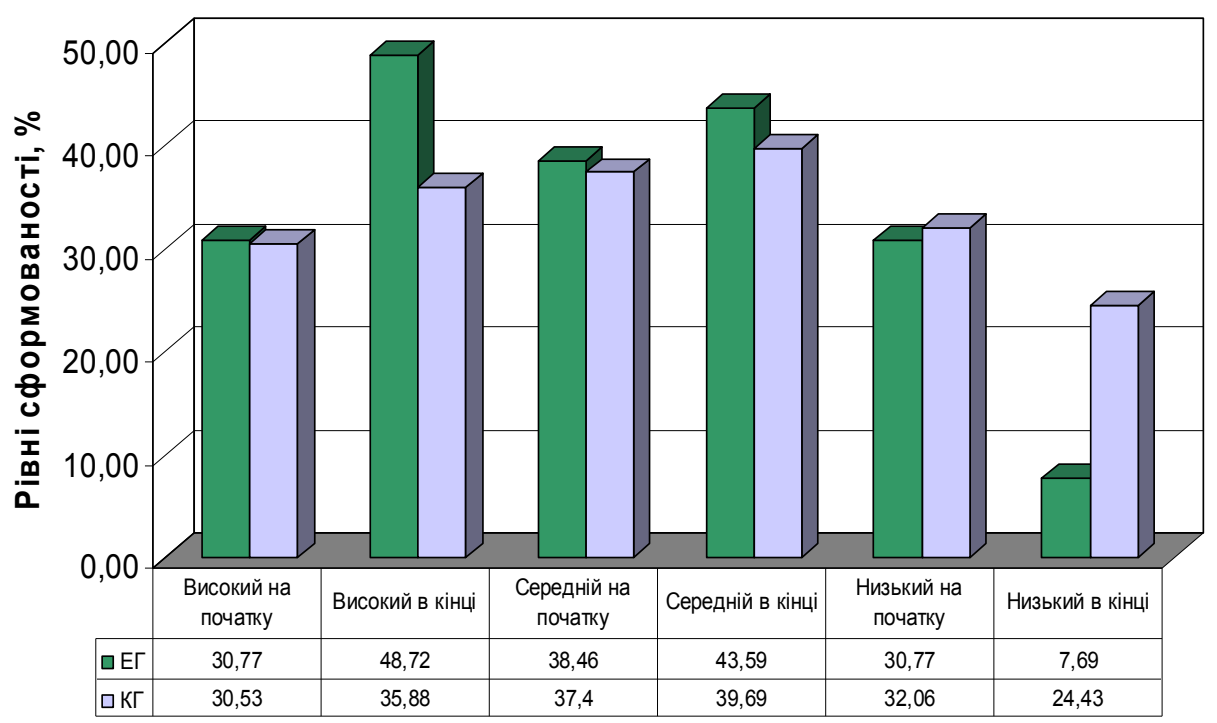

Рис. 2. Розподіл майбутніх магістрів природничих спеціальностей за сформованістю соціально-гуманітарної компетентності

Отже, є всі підстави зробити висновок, що майбутні магістри природничого спрямування ЕГ продемонстрували на кінець педагогічного експерименту кращі результати, ніж майбутні магістри природничого спрямування КГ.

Вірогідність результатів дослідження було перевірено за допомогою критерію Пірсона $\chi^{2}$. Метод $\chi^{2}$ вельми універсальний та застосовується у багатьох психолого-педагогічних дослідженнях оскільки він дозволяє вирішувати велике число різних задач. У нашому дослідженні ми застосовували критерій як розрахунок згоди емпіричного розподілу і передбачуваного теоретичного.

\section{IV Обговорення}

Питання розробки та впровадження дистанційного навчання у сучасну систему вищої освіти нормативно закріплено у документах та положеннях з законодавства України - Національній стратегії розвитку освіти в Україні на період до 2021 року (2013), Законах України «Про освіту» (2017), «Про вищу освіту» (2014), «Положенні про дистанційне навчання» (2013) та $€$ предметом дослідження таких науковців як І. Козубовська [14], В. Кухаренко [15], В. Осадчий [16], Т. Поясок [17], О. Хмель [18]. Серед характерних рис дистанційного навчання, що відрізняють його від традиційної фрорми навчання, виділяють гнучкість, модульність, паралельність, асинхронність, рентабельність, технологічність, мобільність, соціальну рівноправність. Актуальність організації соціально-гуманітарної підготовки 
майбутніх магістрів природничих спеціальностей в умовах дистанційного навчання декількома факторами. Перехід до багаторівневої підготовки фахівців у ЗВО змінює не лише підходи до організації освітнього процесу, а і принципи цілепокладання та самомотивацію тих, хто навчається. Особливо це стосується підготовки магістрів. По-перше, змінюється стиль навчання: значна частина навчального часу проходить не в аудиторії з викладачем, а в режимі самостійної роботи. По-друге, поглиблюється інтеграція навчання 3 науково-дослідною роботою. Замість традиційного репродукування знань студенти залучаються до процесу пошуку та відкриття нових знань. По-третє, змінюється спосіб життя самих студентів: поширеною ситуацією серед магістрів $€$ суміщення навчання і роботи; набирає обертів участь студентів в реалізації спільних освітніх програм українських та закордонних 3ВО.

Отже, дистанційні форми навчання надають широкі можливості при розробці навчальних програм, орієнтованих на активізацію пізнавальної діяльності осіб, що навчаються, підготовки студентів до творчої самостійної роботи, реалізації ідеї індивідуального та диференційованого підходу в процесі навчання [19].

\section{V Висновки}

Таким чином, під час проведення дослідно-експериментальної роботи було перевірено ефективність розробленої технології організації соціально-гуманітарної підготовки майбутніх магістрів природничих спеціальностей в умовах дистанційного навчання та доведено доцільність їі впровадження у освітній процес. Було надано характеристику етапам педагогічного експерименту; викладено особливості реалізації технології досліджуваного феномена та представлено аналіз ії ефективності.

Ефективність реалізації технології організації соціально-гуманітарної підготовки майбутніх магістрів природничих спеціальностей в умовах дистанційного навчання відображено у динаміці рівнів сорормованості соціально-гуманітарної компетентності у майбутніх магістрів контрольної та експериментальної груп. Аналіз результатів КГ та ЕГ засвідчив наявність розбіжності у зміні діагностованих параметрів. Достовірність результатів зафіксованих під час проведення педагогічного експерименту підтверджена за допомогою критерію Пірсона $\chi^{2}$.

Отже, доведено, що результати експериментальної перевірки підтверджують ефективність запропонованої технології організації соціально-гуманітарної підготовки майбутніх магістрів природничих спеціальностей в умовах дистанційного навчання.

\section{Бібліографічні посилання}

1. Кремень В. С. Освіта і наука України: шляхи модернізації (факти, роздуми, перспективи) К. : Грамота, 2002. 216 с.

2. Воронкова Б.А., Дебич М. А., Дем'яненко Н. М., Дівінська Н. О. та ін Оптимізація циклу соціально-гуманітарних дисциплін у вищій освіті України в контексті євроінтеграції : монографрія; за заг. ред. Г. В. Онкович. Київ, 2014. 326 с.

3. Рішення Національного агентства із забезпечення якості вищої освіти від 27 листопада 2019 р. 3 приводу гуманітарної складової освітнього процесу, дотримання мовного законодавства та інших законів України. URL: https://naqa.gov.ua/wp-content/uploads/2019/11/ (дата звернення 28.02.2020).

4. Грабченко А. І., Федорович В. О., Гаращенко Я. М. Методи наукових досліджень: Навч. посібник. Х.: НТУ «ХПІ», 2009. $142 \mathrm{c.}$

5. Сисоєва С.О., Кристопчук Т.Є. Методологія науково-педагогічних досліджень: Підручник. Рівне: Волинські обереги, 2013, 360 c.

6. Педагогіка вищої школи: навч. посібник ; за ред. Курлянд 3.Н. Київ, Знання, 2007. 495 с.

7. Поясок Т. Б., Беспарточна О. І., Герасименко Л. В. Словник термінів з педагогіки вищої школи (українсько-англійський, англо-український): навчальний посібник. Кременчук : ПП Щербатих О.В., 2019. 120 с.

8. Бадмаева Н. Ц. Влияние мотивационного фактора на развитие умственных способностей: Монографрия. Улан-Удэ: издательство ВСГТУ, 2004. 280 с.

9. Бубнова С. С. Методика диагностики индивидуальной структуры ценностных ориентаций личности. Методы психологической диагностики. М.: Изд-во Институт психологии РАН, 1994 Вып. 2.

10. Методика діагностики спрямованості особистості Б.Басса. URL: https://studopedia.com.ua/1_349650_metodikadiagnostiki-spryamovanosti-b-bassa.html. (дата звернення 17.09.2019).

11. Гребень Н. Ф. Психологические тесты для профессионалов. Минск: Современная школа. 2007. 496 с.

12. Фетискин Н. П., Козлов В. В., Мануйлов Г. М. Социально-психологическая диагностика развития личности и малых групп. М.: Издательство Института Психотерапии. 2005. 490 с. 
13. Попенко Н. В. Особливості впровадження елементів дистанційного навчання у процес соціально-гуманітарної підготовки магістрів природничих спеціальностей. Вісник Кременчуцького національного університету імені Михайла Остроградського. Кременчук, 2019. Випуск 3/2019 (116). С.51-58.

14. Козубовська І. В., Сагарда В. В., Пічкар О. П. Дистанційне навчання в системі освіти : навч. посіб. 2-ге вид., перероб., доповн. Ужгород : [б. в.], 2002. 361 c.

15. Кухаренко В. М., Рибалко О. В., Сиротенко Н. Г. Дистанційне навчання: Умови застосування. Дистанційний курс: Навч. пос. Х.: НТУ «ХПІ», «Торсінг», 2002.320 c.

16. Осадчий В., Осадча К. Можливості засобів дистанційного навчання у процесі вивчення технічних дисциплін. Педагогічний дискурс. 2017. Вип. 22. С. 123-128.

17. Поясок Т. Б., Беспарточна О. І. Організація педагогічної взаємодії учасників освітнього процесу в комп'ютерно орієнтованому навчальному середовищі закладу вищої освіти. Інформаційні технології і засоби навчання. 2018. Т. 67, №5, C. $199-212$.

18. Хмель О.В. Фактори, шляхи і умови інтенсифікації та активізації навчальної діяльності студентів у системі дистанційного навчання. Зміст і технології шкільної освіти: Матер. звітної наук. конфр. Ін-ту пед. АПН України. К., 2004. C. $162-164$.

19. Берест Т. М., Берест В. П.. Використання елементів дистанційного навчання в роботі зі студентами стаціонару. Дистанційна освіта України-2013. Інформаційне освітне середовище у системі дистанційного навчання в закладах освіти: інноваційні та психологічні аспекти : зб. наук. пр. Харків. нац. автомоб.-дорож. ун-т. Харків, 2013. С. 17-22.

\section{References}

1. Kremen, V.S. (2002), Osvita i nauka Ukrainy: shliakhy modernizatsii (fakty, rozdumy, perspektyvy). [Education and Science of Ukraine: Ways of Modernization (Facts, Reflections, Prospects)]. Kyiv. 216 p. [in Ukrainian].

2. Voronkova, B. A., Debich, M.A., Demyanenko, N. M., Dyvinskaya, N. O., Onkovych, H. V. and etc. (Eds). (2014). Optymizatsiya tsyklu sotsial'no-humanitarnykh dystsyplin u vyshchiy osviti Ukrayiny v konteksti yevrointehratsiyi: monohrafiya (rukopys). [Optimization of the cycle of social and humanitarian disciplines in higher education of Ukraine in the context of European integration: monograph (manuscript)]. Kyiv. 326 p. [in Ukrainian].

3. Decision of the National Agency for Quality Assurance in Higher Education of November 27, 2019 regarding the humanitarian component of the educational process, compliance with language legislation and other laws of Ukraine. URL: https://naqa.gov.ua/wp-content/uploads/2019/11/ (Accessed 28 February 2020) [in Ukrainian].

4. Hrabchenko, A.I., Fedorovych, V.O., Harashchenko, Ya.M. (2009). Metody naukovykh doslidzhen: Navch. posibnyk. [Research Methods: A Textbook]. Kharkiv. NTU "KhPI". 142 p. [in Ukrainian].

5. Sysoieva, S.O., Krystopchuk, T.le. (2013) Metodolohiia naukovo-pedahohichnykh doslidzhen: Pidruchnyk. [Methodology of scientific and pedagogical research: A textbook.]. Rivne. Volyn charms. 360 p. [in Ukrainian].

6. Kurliand, Z.N. (Ed). (2007). Pedahohika vyshchoi shkoly: Navch. posibnyk. [Pedagogy of high school: A textbook]. Kyiv. Knowledge. 495 p. [in Ukrainian].

7. Poiasok, T.B., Bespartochna, O.I., Herasymenko, L.V. (2019). Slovnyk terminiv z pedahohiky vyshchoi shkoly (ukrainskoanhliiskyi, anhlo-ukrainskyi): navchalnyi posibnyk. [Dictionary of Terms in Higher Education Pedagogy (Ukrainian-English, English-Ukrainian): A textbook.]. Kremenchuk. PP Shcherbatykh O.V. 120 p. [in Ukrainian].

8. Badmayeva, N.Ts. (2004). Vliyaniye motivatsionnogo faktora na razvitiye umstvennykh sposobnostey: Monografiya. [The influence of the motivational factor on the development of mental abilities: Monograph]. Ulan-Ude: publishing house of VSTU. 280 p. [in Russian].

9. Bubnova, S.S. (1994). Metodika diagnostiki individual'noy struktury tsennostnykh oriyentatsiy lichnosti. Metody psikhologicheskoy diagnostiki. [Diagnostic technique of the individual structure of value orientations of the personality. Methods of psychological diagnosis]. Moscow. Publishing House Institute of Psychology RAS, Vol. 2. [in Russian].

10. Method of diagnostics of B. Bass's personality orientation. https://studopedia.com.ua/1_349650_metodika-diagnostikispryamovanosti-b-bassa.html. [in Ukrainian].

11. Greben', N.F. (2007). Psikhologicheskiye testy dlya professionalov. [Psychological tests for professionals]. Minsk: Modern School. 496 p. [in Russian].

12. Fetiskin, N.P., Kozlov, V.V., Manuylov G.M. (2005) Sotsial'no-psikhologicheskaya diagnostika razvitiya lichnosti i malykh grupp. [Socio-psychological diagnosis of the development of personality and small groups]. Moscow. Publishing house of the Institute of Psychotherapy. 490 p. [in Russian].

13. Popenko, N.V. (2019). Osoblyvosti vprovadzhennia elementiv dystantsinoho navchannia u protses sotsialno-humanitarnoi pidhotovky mahistriv pryrodnychykh spetsialnostei. [Features of distance learning elements implementation in the process of social and humanitarian training of masters of natural specialties]. Visnyk Kremenchutskoho natsionalnoho universytetu imeni Mykhaila Ostrohradskoho. [Bulletin of the Kremenchuk Mikhailo Ostrohradskyi National University]. Kremenchuk, 2019. Issue 3/2019 (116). 51-58 pp. [in Ukrainian].

14. Kozubovska, I. V., Saharda, V. V., Pichkar, O. P. (2002). Dystantsiine navchannia v systemi osvity. Uzhhorod [in Ukrainian].

15. Kukharenko, V.M., Rybalko, O.V., Syrotenko, N.H. (2002). Dystantsiine navchannia: umovy zastosuvannia : dystantsiinyi kurs. Kharkiv: Torsinh. 320 p. [in Ukrainian].

16. Osadchyi, V., Osadcha, K. (2017). Possibilities of Distance Learning Tools in Teaching and Learning Technical Subjects, Pedagogical Discourse, 2017, Issue 22, 123-128 pp. [in Ukrainian]. 
17. Poiasok, T.B., Bespartochna, O.I. (2018). Orhanizatsiia pedahohichnoi vzaiemodii uchasnykiv osvitnoho protsesu $v$ kompiuterno oriientovanomu navchalnomu seredovyshchi zakladu vyshchoi osvity. [Arrangement of pedagogical ineraction among the education process participants in computer oriented educational environment of a higher education institution]. Informatsiini tekhnolohii i zasoby navchannia. [Information technologies and learning tools]. Vol. 67, no 5, pp. 199-212. [in Ukrainian].

18. Khmel, O.V. (2004). Faktory, shliakhy i umovy intensyfikatsii ta aktyvizatsii navchalnoi diialnosti studentiv u systemi dystantsiinoho navchannia. [Factors, ways and conditions of intensification and activation of students' educational activity in the distance learning system]. Zmist i tekhnolohii shkilnoi osvity. Mater. zvitnoi nauk. konf. In-tu ped. APN Ukrainy [Content and Technology of School Education: Proceedings of the Reporting Scientific Conference of the Institute of Pedagogy of the APS of Ukraine. Kyiv. 162-164 pp. [in Ukrainian].

19. Berest, T.M., Berest, V.P. (2013) Vykorystannia elementiv dystantsiinoho navchannia v roboti zi studentamy statsionaru. [Using distance learning elements in working with full-time students]. Dystantsina osvita Ukrainy-2013. Informatsiine osvitnie seredovyshche u systemi dystantsiinoho navchannia v zakladakh osvity: innovatsiini ta psykholohichni aspekty : zb. nauk. pr. Kharkiv. nats. avtomob.-dorozh. un-t. [Distance education of Ukraine-2013. Information Educational Environment in the Distance Learning System in Educational Institutions: Innovative and Psychological Aspects: Collection of Scientific Papers]. Kharkiv. KHADI. 17-22 pp. [in Ukrainian].

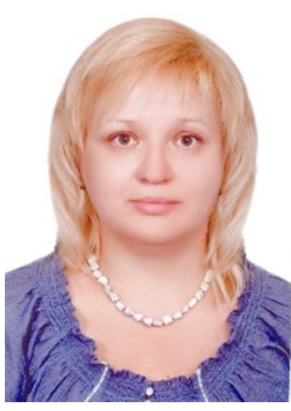

Попенко Наталія Володимирівна,

Фахівець

Харківський національний університет імені В.Н. Каразіна,

Майдан Свободи, 4, м. Харків, Україна, 61022

Тел. (063) 4000613 . E-mail: popenko_nata@ukr.net

\section{Popenko Nataliia Volodymyrivna,}

Specialist

V.N.Karazin Kharkiv National University,

4 Svobody Sq., Kharkiv, Ukraine, 61022

Tel. +38 (063) 4000613 .E-mail: popenko_nata@ukr.net

ORCID: 0000-0003-1660-4573

\section{Citation (APA):}

Popenko, N. (2020). Socio-Humanitarian Training Arrangement Technology Implementation for the Future Masters of Natural Specialties under the Distance Learning Conditions. Engineering and Educational Technologies, 8 (1), 19-31. doi:

https://doi.org/10.30929/2307-9770.2020.08.01.02

\section{Цитування (ДСТУ 8302:2015):}

Попенко Н. В. Реалізація технології організації соціально-гуманітарної підготовки майбутніх магістрів природничих спеціальностей в умовах дистанційного навчання / Інженерні та освітні технології. 2020. Т. 8. № 1. С. 19-31. doi: https://doi.org/10.30929/2307-9770.2020.08.01.02

Обсяг статmі: $\quad$ сторінок - 13 ; умовних друк. аркушів - 1,883 . 